Article

\title{
An Improved Methodology for Determination of Fluorine in Biological Samples Using High-Resolution Molecular Absorption Spectrometry via Gallium Fluorine Formation in a Graphite Furnace
}

\author{
Andrzej Gawor (D), Andrii Tupys, Anna Ruszczyńska (D) and Ewa Bulska * \\ Biological and Chemical Research Centre, Faculty of Chemistry, University of Warsaw, Żwirki i Wigury 101, \\ 02-089 Warsaw, Poland; agawor@chem.uw.edu.pl (A.G.); atupys@cnbc.uw.edu.pl (A.T.); \\ aruszcz@chem.uw.edu.pl (A.R.) \\ * Correspondence: ebulska@chem.uw.edu.pl
}

check for updates

Citation: Gawor, A.; Tupys, A.; Ruszczyńska, A.; Bulska, E. An Improved Methodology for Determination of Fluorine in Biological Samples Using HighResolution Molecular Absorption Spectrometry via Gallium Fluorine Formation in a Graphite Furnace. Appl. Sci. 2021, 11, 5493. https:// doi.org/10.3390/app11125493

Academic Editor: Giuseppe Lazzara

Received: 12 May 2021

Accepted: 12 June 2021

Published: 14 June 2021

Publisher's Note: MDPI stays neutral with regard to jurisdictional claims in published maps and institutional affiliations.

Copyright: (c) 2021 by the authors. Licensee MDPI, Basel, Switzerland. This article is an open access article distributed under the terms and conditions of the Creative Commons Attribution (CC BY) license (https:// creativecommons.org/licenses/by/ $4.0 /)$.
Featured Application: Determination of trace amounts of fluorine in biological samples using highresolution molecular absorption spectrometry via gallium fluorine formation in a graphite furnace.

Abstract: Nowadays growing attention is paid to the control of fluorine content in samples of biological origin as it is present in the form of various biologically active organic compounds. Due to the chemically-rich matrix of biological tissues, the determination of fluorine becomes a very difficult task. Furthermore, a required complex sample preparation procedure makes the determination of the low contents of F by ion chromatography UV-Vis or ion-selective electrodes not possible. High-resolution continuum source graphite furnace molecular absorption spectrometry (HR-CS GF MAS) seems to be the best option for this purpose due to its high robustness to matrix interferences, especially in the presence of carefully selected modifiers. In this work the possibility of quantitative $\mathrm{F}$ determination in water and animal tissues was examined by measuring the molecular absorption of gallium monofluoride $(\mathrm{GaF})$ at $211.248 \mathrm{~nm}$ with the use of a commercially available HR-CS GF MAS system. Experimental conditions for the sensitive and precise determination of fluorine were optimized, including the time/temperature program as well as addition of gallium and modifier mixture in combined mode. Under these conditions the fluoride present in the sample was stabilized up to $600{ }^{\circ} \mathrm{C}$, and the optimum vaporization temperature for $\mathrm{GaF}$ was $1540{ }^{\circ} \mathrm{C}$. Palladium and zirconium deposited onto the graphite surface served as solid modifiers; sodium acetate and ruthenium modifiers were added directly to the sample. The limit of detection and the characteristic mass of the method were $0.43 \mu \mathrm{g} / \mathrm{L}$ and $8.7 \mathrm{pg}$, respectively. The proposed procedure was validated by the use of certified reference materials (CRMs) of lake water and animal tissue; the acceptable recovery was obtained, proving that it can be applied for samples with a similar matrix.

Keywords: high-resolution continuum source graphite furnace molecular absorption spectrometry; fluorine determination; gallium monofluoride

\section{Introduction}

The interest in the determination of fluorine increased over decades, which is due to its significant role in environment as well as in biological system. Although not a first one, though interesting work was published in 1941 by the U.S. National Bureau of Standards [1] on the quantitative determination of fluorine in organic compounds. Since that time a large number of papers has been published on the analytical procedure used for the determination of fluorine. The application of commonly used optical spectroscopy (inductively coupled plasma optical emission spectrometry-ICP-OES; atomic absorption spectroscopy-AAS) is limited due to the resonance lines of the fluorine being below 
$100 \mathrm{~nm}$ [2], also a very high ionisation potential $(17.42 \mathrm{eV})$ limits the use of both optical techniques but also inductively coupled plasma mass spectrometry (ICP-MS). In practice fluorine has been determined, e.g., by ion-selective electrodes (ISE) [3], ion chromatography (IC) with electrochemical conductivity detector [4], UV-VIS [5] or cavity ring-down spectroscopy (CRDS) coupled with helium microwave-induced plasma [6]. Nonetheless, these techniques do not fulfil the specific requirements to be applicable for fluorine determination in biological objects.

Another nonconventional technique that can be applied in F determination is molecular absorption spectrometry (MAS) with the use of high-resolution continuum source (HR-CS MAS), which performance can be increased in the presence of matrix modifiers, and also those with the ability to serve as pretreatment modifiers as it was proposed for GF AAS measurements [7-11]. Interestingly, this technique is still not sufficiently explored, yet remains important in the field of molecular spectrometry, providing a resolution $(\mathrm{k} / \mathrm{Dk})$ of 175,000 in a $0.3 \mathrm{~nm}^{-1} \mathrm{~nm}$ range, corresponding to a bandwidth of $1.6 \mathrm{pm}$ per pixel at $200 \mathrm{~nm}$ to $6.4 \mathrm{pm}$ at $800 \mathrm{~nm}$ [12]. Fluorine is the most studied element via HR-CS MAS with graphite furnace (GF) atomization, among all halogens. This is mostly due to the high sensitivity that is provided by a formation of monofluoride molecules with selected metals. The limit of detection (LOD) for most halogens is at the level of nanograms, while for $\mathrm{F}$ a picogram level was achieved. The selectivity of $\mathrm{F}$ determination is usually better than for other halogens, as it is known to create stronger bonds with metals [13]. Fluorine can form the following molecules that are stable in gaseous form: $\mathrm{GaF}[2,14], \mathrm{CaF}[15,16]$, $\operatorname{SrF}[17,18]$ or AlF $[19,20]$, which offer the possibility of generating specific monofluoride molecules for a given matrix. Although AlF, $\mathrm{CaF}$ and $\mathrm{SrF}$ are known to be more thermally stable $[15,17,19]$ than $\mathrm{GaF}$, the last one [14] has been shown to be preferred in fluorine determination by HR-CS GF MAS due to the better sensitivity with the support of tailored modifier compositions and robustness concerning interferences thanks to the high spectral resolution. The only requirement is that the $\mathrm{F}$ has to be accompanied by a complex mixture of modifiers for the best performance.

Among the main applications of HR-CS GF MAS for F determination, the analyses of water [17], soil [21], coal [22], milk [16], baby food [23], flour [24], tea [15], fish and seafood [25], eye shadow [26] and etching solutions from the photovoltaic industry [20] can be mentioned. In most of these applications $\mathrm{Ca}$ was used as a molecule-forming agent and only in some cases were $\mathrm{Al}$ or $\mathrm{Sr}$ also applied. The samples were placed in the furnace without any treatment or only after a dilution with water. The molecular absorbance of $\mathrm{GaF}$ can also be applied for analysis of $\mathrm{F}$ in samples with relatively high fluorine content (e.g., toothpaste [27], novel fluorinated biological and environmental compounds [28,29], drug candidates [30]), as well as in samples with only trace amounts of $\mathrm{F}$, such as drinking, mineral and river water $[2,31,32]$ or cancer cells containing a fluorinated drug [33]). Nevertheless, most of these procedures have issues such as the need for sample pretreatment by using high-performance liquid chromatography (HPLC) coupled off-line to HR-CS GF MAS or troublesome automated sampling of insignificant amounts of a biological sample (e.g., animal tissue). The first attempt at fluorine quantification in liver tissues from rats treated with fluorinated drugs was described in our previous work [34]. To the best of our knowledge, this was the first attempt to apply HR-CS GF MAS for analysis of $\mathrm{F}$ in samples of animal origin after acid digestion.

The aim of this work is to design and validate the improved analytical protocol for determination of the total content of fluorine in selected biological tissues directly after acid digestion via monitoring of $\mathrm{GaF}$ molecules intended for trace amounts of $\mathrm{F}$ in samples.

\section{Materials and Methods}

\subsection{Instrumentation and Operating Conditions}

A high-resolution continuum source atomic absorption spectrometer ContrAA 700 (Analytik Jena, Jena, Germany) with a transversely heated graphite tube atomizer was used for the measurement of total fluorine. The developed procedure applies the generation of 
gallium monofluoride (GaF) followed by monitoring of its molecular absorption [2]. The instrument is equipped with a $300 \mathrm{~W}$ xenon short-arc lamp (XBO 301, GLE, Dortmund, Germany) operating in a hot-spot mode as a continuous radiation source for the wavelength range from $185 \mathrm{~nm}-900 \mathrm{~nm}$, high resolution double monochromator consisting of a prism for pre-dispersion, an echelle monochromator and a charge-coupled device (CCD) array detector. All measurements were performed using pyrolytically coated graphite tubes with integrated PIN-platform (Analytik Jena); the molecular absorption of gallium monofluoride $(\mathrm{GaF})$ was measured at $211.248 \mathrm{~nm}$, within the spectral range $211.1215 \mathrm{~nm}$ and $211.3732 \mathrm{~nm}$. The optimized graphite furnace temperature/time program used for fluorine total content determination is shown in Table 1. More details are provided in Section 3.1.

Table 1. Graphite furnace temperature/time program for $\mathrm{Pd} / \mathrm{Zr}$ modifier and Ga deposition on graphite furnace (steps 1-5); addition of sodium acetate and ruthenium modifier (step 6). Sample thermal pretreatment (steps 7 to 10) and GaF molecules evaporation (step 11).

\begin{tabular}{ccccc}
\hline Step & Process & $\begin{array}{c}\text { Temperature } \\
{\left[{ }^{\circ} \mathbf{C}\right]}\end{array}$ & $\begin{array}{c}\text { Ramp } \\
{\left[{ }^{\circ} \mathbf{C} / \mathbf{s}\right]}\end{array}$ & $\begin{array}{c}\text { Hold } \\
{[\mathbf{s}]}\end{array}$ \\
\hline 1 & Drying I & 80 & 7 & 2 \\
\hline 2 & Drying II & 95 & 10 & 20 \\
\hline 3 & Drying III & 120 & 20 & 10 \\
\hline 4 & Drying IV & 350 & 200 & 10 \\
\hline 5 & Pretreatment & 1100 & 300 & 10 \\
\hline 6 & Cooling & 70 & - & 20 \\
\hline 7 & Sample injection & 70 & 20 & 30 \\
\hline 8 & Drying & 105 & 550 & 10 \\
\hline 9 & Pyrolysis & 600 & - & 5 \\
\hline 10 & Auto Zero & 600 & 1540 & 7 \\
\hline 11 & Vaporization & 1540 & 500 & 4 \\
\hline 12 & Clean & 2450 & & \\
\hline
\end{tabular}

\subsection{Reagents and Solutions}

Analytical reagent grade chemicals were used (Merck, Darmstadt, Germany; EMD Millipore, Darmstadt, Germany). Fluoride standard solution traceable to a standard reference material (SRM) from the National Institute of Standards and Technology (NIST, Gaithersburg, MD, USA) NaF in $\mathrm{H}_{2} \mathrm{O}(1000 \mathrm{mg} / \mathrm{L} \mathrm{F})$ was purchased from Merck. Certified Reference Materials (CRM) were used: bovine liver tissue NIST 1577c (NIST); MODAS-5 cod tissue (Consortium MODAS, Warsaw, Poland); CRANBERRY-05 lake water; ONTARIO12 lake water (Environment and Climate Change Canada, Ottawa, ON, Canada). Analytical grade nitric acid, 65\% (EMD Millipore) was used for sample digestion. Samples and standards were diluted with deionized water obtained by a Milli-Q System (18.2 M $\Omega$ $\mathrm{cm}$; EMD Millipore). Palladium nitrate ( $2 \% \mathrm{Pd}$ in $5 \% \mathrm{HNO}_{3}$, SPC Science, Ottawa, ON, Canada), zirconium ICP standard $\left(\mathrm{ZrCl}_{4}\right.$ in $7 \% \mathrm{HCl}, 1000 \mathrm{mg} / \mathrm{L} \mathrm{Zr}$, Merck), ruthenium $(1000 \mathrm{mg} / \mathrm{L} \mathrm{Ru}$ in $20 \% \mathrm{HCl}$, VHG Labs, USA) solutions and sodium acetate trihydrate (Avantor ${ }^{\text {TM }}$ Performance Materials Poland S.A., Gliwice, Poland) were used for preparation of modifiers solutions. Gallium(III) nitrate hydrate (99.9\%, Merck, Darmstadt, Germany) was used as molecule-forming agent.

\subsection{Sample Preparation}

A microwave system UltraWAVE (Milestone, Sorisole, Italy) was used for the digestion of biological CRMs for the determination of total content of fluorine. The digestion of around $300 \mathrm{mg}$ of samples (bovine liver or cod tissues) in concentrated nitric acid was performed under the following program: $20 \mathrm{~min}$ up to $220^{\circ} \mathrm{C}$ and $15 \mathrm{~min}$ at $220^{\circ} \mathrm{C}$. In 
order to protect the graphite surface, the cooled digests were slightly diluted with water to a final concentration of $\mathrm{HNO}_{3}$ of around $20 \%$, still exhibiting low pH below 2 .

\section{Results and Discussion}

\subsection{Method Development}

In the case of HR-CS MAS the method development covers the optimization of temperatures of main processes, e.g., the process of thermal deposition of modifiers, then thermal pretreatment of the sample as such, and finally the formation of di-molecules containing fluorine. The conditions for pyrolysis of the sample and for the process of $\mathrm{GaF}$ formation as well as its vaporization are crucial, as they affect the sensitivity of the determination of fluorine. The initial experimental conditions were adopted from [27], but as they did not provide the expected sensitivity and precision of results, the careful optimization of all parameters were carried out. Then the selection of the wavelength range for the monitoring of molecular absorption signal for $\mathrm{GaF}$ as well as its closed surrounding leaded to the range between $211.1215 \mathrm{~nm}$ and $211.3732 \mathrm{~nm}$, which is very close to values published in recent paper (e.g., $211.1230 \mathrm{~nm}-211.3718 \mathrm{~nm}$ [35]). The selected range cover also the atomic line of $\mathrm{Ga}(211.196 \mathrm{~nm})$ [33], which ensure the monitoring of the presence of gallium atoms in gaseous phase.

\subsubsection{Pyrolysis and Vaporization Conditions}

The pyrolysis and vaporization curve for an aqueous solution of $\mathrm{NaF}(20 \mu \mathrm{L}$ of the $100 \mu \mathrm{g} / \mathrm{L}$ solution) are given in Figure 1. Interestingly, changing the pyrolysis temperature, integrated absorbance increased for about $15 \%$ within the range from $300{ }^{\circ} \mathrm{C}$ to $580{ }^{\circ} \mathrm{C}$, then a narrow range between $580^{\circ} \mathrm{C}$ and $640^{\circ} \mathrm{C}$ with a plateau was observed. After that a typical dropdown of the integrated absorbance was noticed and a complete analyte loss at $1300^{\circ} \mathrm{C}$.

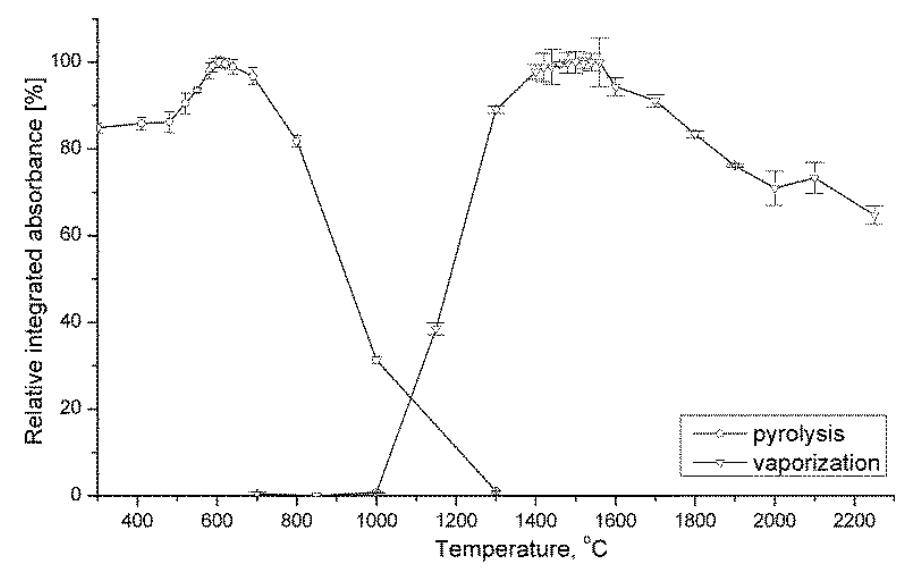

Figure 1. Dependence of $\mathrm{GaF}$ molecule relative absorbance at $211.248 \mathrm{~nm}$ on vaporization temperature $\left(T_{\text {vapor. }}\right)\left(T_{\text {pyrol. }}=550{ }^{\circ} \mathrm{C}\right)$ and pyrolysis temperature $\left(T_{\text {pyrol. }}\right)\left(T_{\text {vapor. }}=1540{ }^{\circ} \mathrm{C}\right) ; m(\mathrm{Pd})=5.0 \mu \mathrm{g}$; $m(\mathrm{Zr})=0.1 \mu \mathrm{g} ; m(\mathrm{Ru})=3.0 \mu \mathrm{g} ; C\left(\mathrm{Ga}_{\text {pretr. }}\right)=50 \mu \mathrm{g} ; m\left(\mathrm{Ga}_{\text {sol. }}\right)=20 \mu \mathrm{g} ; m\left(\mathrm{CH}_{3} \mathrm{COONa}\right)=5.0 \mu \mathrm{g}$.

A pyrolysis temperature of $600{ }^{\circ} \mathrm{C}$ was chosen as an optimum for all further experiments. Comparing to previous reports, where $500{ }^{\circ} \mathrm{C}[14,30,31,36]$ and $550{ }^{\circ} \mathrm{C}[2,27-29]$ were applied, selected conditions assure more efficient removal of volatile matrix components. Indeed, even higher pyrolysis temperature was reported $\left(700{ }^{\circ} \mathrm{C}\right.$ [33]) with the mixture of zirconium and calcium as chemical modifiers. Despite reaching a higher pyrolysis temperature, it is worth to notice possible interferences of $\mathrm{CaF}$ on the $\mathrm{GaF}$, thus this option was withdrawn from further consideration.

Changing the vaporization temperature, the appearance of gallium monofluoride in gaseous phase can be registered above $1000^{\circ} \mathrm{C}$. Then the integrated absorbance increases rapidly between $1000{ }^{\circ} \mathrm{C}-1400{ }^{\circ} \mathrm{C}$ reaching the plateau within $1400^{\circ} \mathrm{C}-1600{ }^{\circ} \mathrm{C}$. The further increase of vaporization temperature leads to a consistent absorbance decrease that refers to 
an analyte loss caused most probably by thermal decomposition of $\mathrm{GaF}$, as it occurs in the case of $\mathrm{CaF}$ [21]. More detailed measurements were carried out within the plateau range to establish conditions assuring best sensitivity accompanied with the best precision of measurements, expressed as lowest relative standard deviation. The optimum temperature for $\mathrm{GaF}$ vaporization turned out to be $1540{ }^{\circ} \mathrm{C}$ and as it is consistent with those previously reported $[2,27,31,36]$, it was used in all further investigations.

\subsubsection{Effect of $\mathrm{Pd} / \mathrm{Zr}$ Modifier}

Indirect measurement of $\mathrm{F}$ in a form of $\mathrm{GaF}$ molecule requires the application of palladium as a modifier to enhance the efficiency of the transformation into $\mathrm{GaF}$, to avoid the low-temperature fluorine losses, mainly in the form of volatile HF, and to obtain a sharp molecular absorption signal [2]. Additional use of $\mathrm{Zr}$ was also proposed, which usually results in a considerable increase in sensitivity [14]; moreover is known to support suppression of phosphorus monoxide formation (PO) [37]. An attempt was made to use a mixture of $\mathrm{Pd} / \mathrm{Zr}$ as a modifier, thermally pretreated before each sample injection; mainly to find out the optimum modifier masses in order to achieve the best performance in respect to the sensitivity.

For this purpose different amounts of the mixture of $\mathrm{Pd} / \mathrm{Zr}$ were deposited onto the graphite furnace in order to find optimal amount and still to compare with values reported by Gleisner et al. [2] ( $m_{0}, 5 \mu \mathrm{g}$ of Pd and $0.1 \mu \mathrm{g}$ of $\left.\mathrm{Zr}\right)$. It turned out that the application of 1.5 times higher masses of modifiers than previously reported values results in an increase in sensitivity of about $10 \%$ (Figure 2). However, further addition of higher masses of $\mathrm{Pd} / \mathrm{Zr}$ modifier led to a gradual and considerable decrease in signal intensity. The addition of $7.5 \mu \mathrm{g}$ of $\mathrm{Pd}$ and $0.15 \mu \mathrm{g}$ of $\mathrm{Zr}$ was considered as the best option and was used in all further investigations.

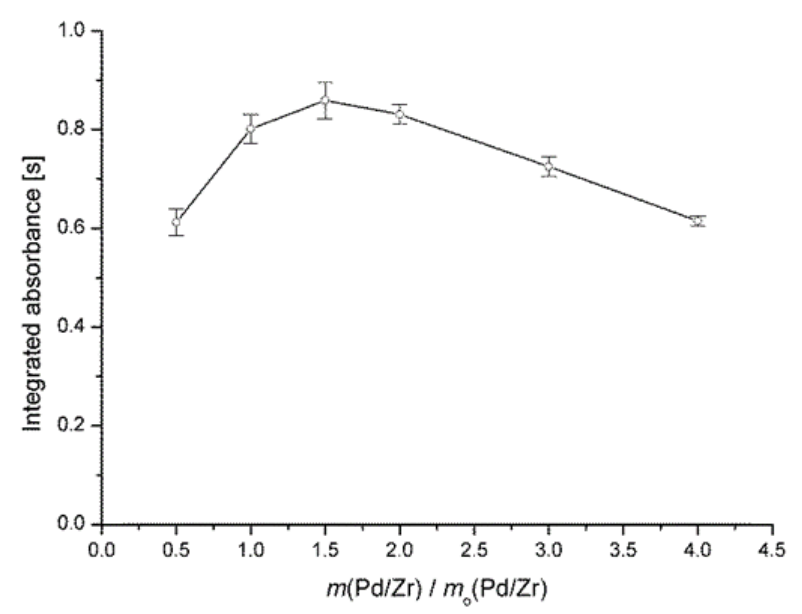

Figure 2. Dependence of GaF molecule absorbance at $211.248 \mathrm{~nm}$ on the relative mass of palladium/zirconium modifier used for furnace pretreatment; $\mathrm{T}_{\text {pyrol. }}=600{ }^{\circ} \mathrm{C} ; \mathrm{T}_{\text {vapor. }}=1540{ }^{\circ} \mathrm{C}$; $m_{\mathrm{o}}(\mathrm{Pd})=5.0 \mu \mathrm{g} ; m_{\mathrm{o}}(\mathrm{Zr})=0.1 \mu \mathrm{g}[2] ; m(\mathrm{Ru})=3.0 \mu \mathrm{g} ; C\left(\mathrm{Ga}_{\text {pretr. }}\right)=50 \mu \mathrm{g} ; m\left(\mathrm{Ga}_{\text {sol. }}\right)=20 \mu \mathrm{g}$; $m\left(\mathrm{CH}_{3} \mathrm{COONa}\right)=5.0 \mu \mathrm{g}$.

\subsubsection{Effect of $\mathrm{Ru}(\mathrm{III})$ Modifier}

It is also know that some transition metals, such as ruthenium, can significantly enhance the formation of $\mathrm{GaF}$ by reducing the interfering formation of $\mathrm{GaO}$, which usually results in further sensitivity increase [2]. In our approach, instead of $\mathrm{Ru}(\mathrm{III})$ nitrosyl nitrate [2], the solution of $\mathrm{RuCl}_{3}$ in $\mathrm{HCl}$ was used and the mass of modifier was optimized versus the intensity of $\mathrm{GaF}$ signal. The results shown in Figure 3 indicate that the optimum mass of ruthenium introduced in a form of $\mathrm{RuCl}_{3}$ in $20 \% \mathrm{HCl}$ is around $1 \mu \mathrm{g}$. Thus with the applied time/temperature program for graphite furnace, the amount of $3 \mu \mathrm{g}$ of Ru recommended in literature $[2,34]$ is not necessary for the best sensitivity. 


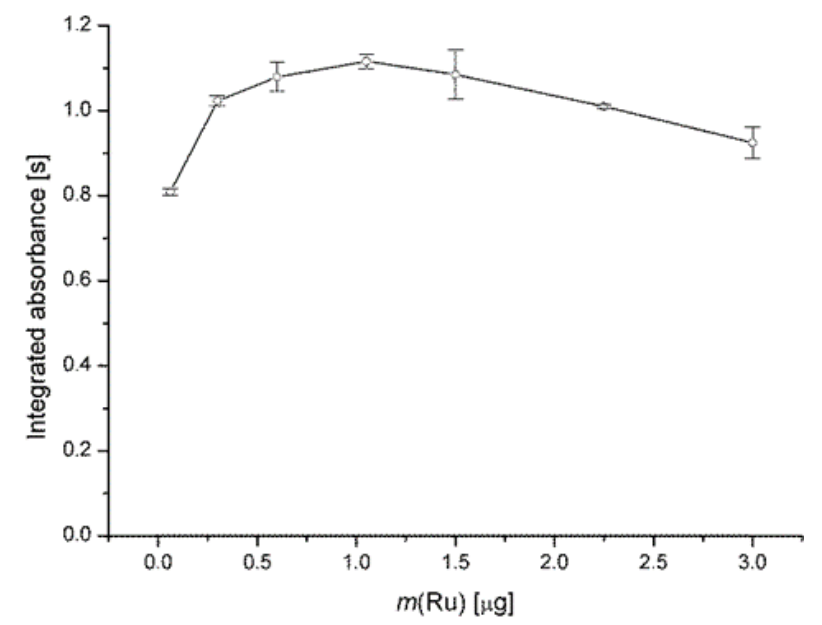

Figure 3. Dependence of GaF molecule absorbance at $211.248 \mathrm{~nm}$ on the mass of ruthenium in the modifier solution; $T_{\text {pyrol. }}=600{ }^{\circ} \mathrm{C} ; \mathrm{T}_{\text {vapor. }}=1540{ }^{\circ} \mathrm{C} ; m(\mathrm{Pd})=7.5 \mu \mathrm{g} ; m(\mathrm{Zr})=0.15 \mu \mathrm{g}$; $C\left(\mathrm{Ga}_{\text {pretr. }}\right)=50 \mu \mathrm{g} ; m\left(\mathrm{Ga}_{\text {sol. }}\right)=20 \mu \mathrm{g} ; m\left(\mathrm{CH}_{3} \mathrm{COONa}\right)=5.0 \mu \mathrm{g}$.

\subsubsection{Optimization of the Amount of Gallium}

The last step of the optimization process was the search for the highest yield of GaF molecules formation by adding increasing amounts of gallium(III) nitrite monohydrate as a molecule-forming agent. For this purpose, we used the combined mode of the application of gallium as molecule forming agent solution, meaning that part of gallium was deposited on the surface of graphite along with the Pd/Zr modifier (step 1-5 in Table 1), and part of gallium was added directly to the sample, then introduced together at step 7 (Table 1).

In order to optimize the amount of gallium introduced in both modes, firstly different masses, up to $600 \mu \mathrm{g}$ of $\mathrm{Ga}$, were deposited onto the graphite surface, when $20 \mu \mathrm{g}$ of Ga were still added with the sample as in our previous work [34]. The results show that the integrated absorbance grows as the amount of Ga grows (Figure 4), indicating that the formation of $\mathrm{GaF}$ is correlated with the mass of $\mathrm{Ga}$ deposited on the graphite. A value of $500 \mu \mathrm{g} \mathrm{Ga}$ (III) ( $25 \mu \mathrm{L}$ of the $20 \mathrm{~g} / \mathrm{L}$ solution) was selected for further investigation due to the following technical limitations: (1) it is not recommended to inject more than $50 \mu \mathrm{L}$ of all solutions into the graphite tube with integrated PIN platform; (2) the solutions of $\mathrm{Ga}\left(\mathrm{NO}_{3}\right)_{3}$ become turbid at the $\mathrm{Ga}(\mathrm{III})$ concentration higher than $25 \mathrm{~g} / \mathrm{L}$.

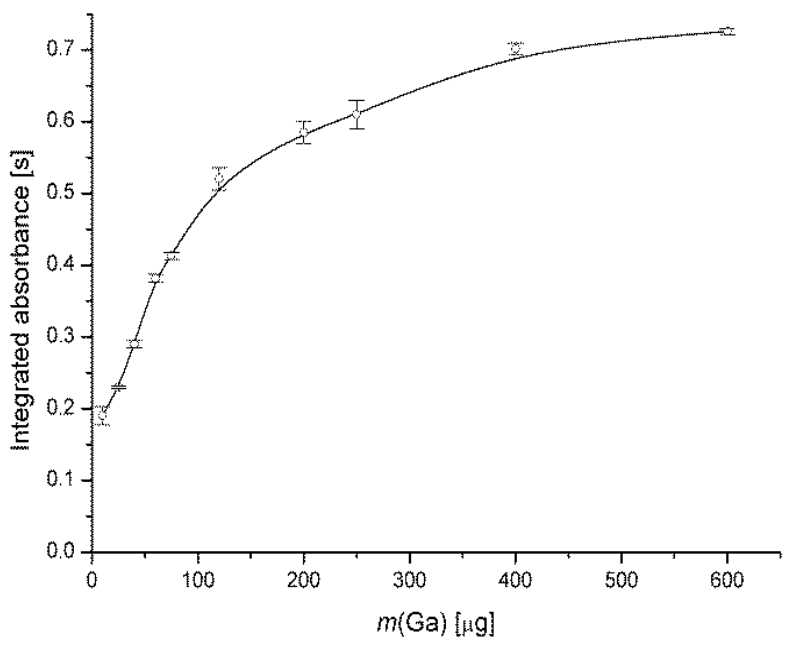

Figure 4. Dependence of GaF molecule absorbance at $211.248 \mathrm{~nm}$ on Ga mass added for furnace pretreatment; $T_{\text {pyrol. }}=600{ }^{\circ} \mathrm{C} ; T_{\text {vapor. }}=1540{ }^{\circ} \mathrm{C} ; m(\mathrm{Pd})=7.5 \mu \mathrm{g} ; m(\mathrm{Zr})=0.15 \mu \mathrm{g} ; m(\mathrm{Ru})=1.0 \mu \mathrm{g}$; $m\left(\mathrm{Ga}_{\mathrm{sol}}\right)=20 \mu \mathrm{g} ; m\left(\mathrm{CH}_{3} \mathrm{COONa}\right)=5.0 \mu \mathrm{g}$. 
The alternative option is the addition of gallium(III) nitrite monohydrate solution into the furnace together with the sample solution. In this work we use the combined mode of the use of gallium, as to support the $\mathrm{GaF}$ formation on two levels, deposited on the graphite surface and being present in the solutions. Two amounts of Ga (60 $\mu \mathrm{g}$ and $800 \mu \mathrm{g})$ were selected for the evaluation of the performance of gallium as $\mathrm{GaF}$ molecular formation agent.

According to Figure 5, samples with a low amount of Ga used for pretreatment have usually $20-30 \%$ lower light absorbance than those from the second set with a high mass of Ga even at high contents of Ga taken together with the sample directly before the measurement. In order to obtain much more robust results and higher signal intensity it is recommended to introduce higher masses of Ga during thermal pretreatment than together with the sample.
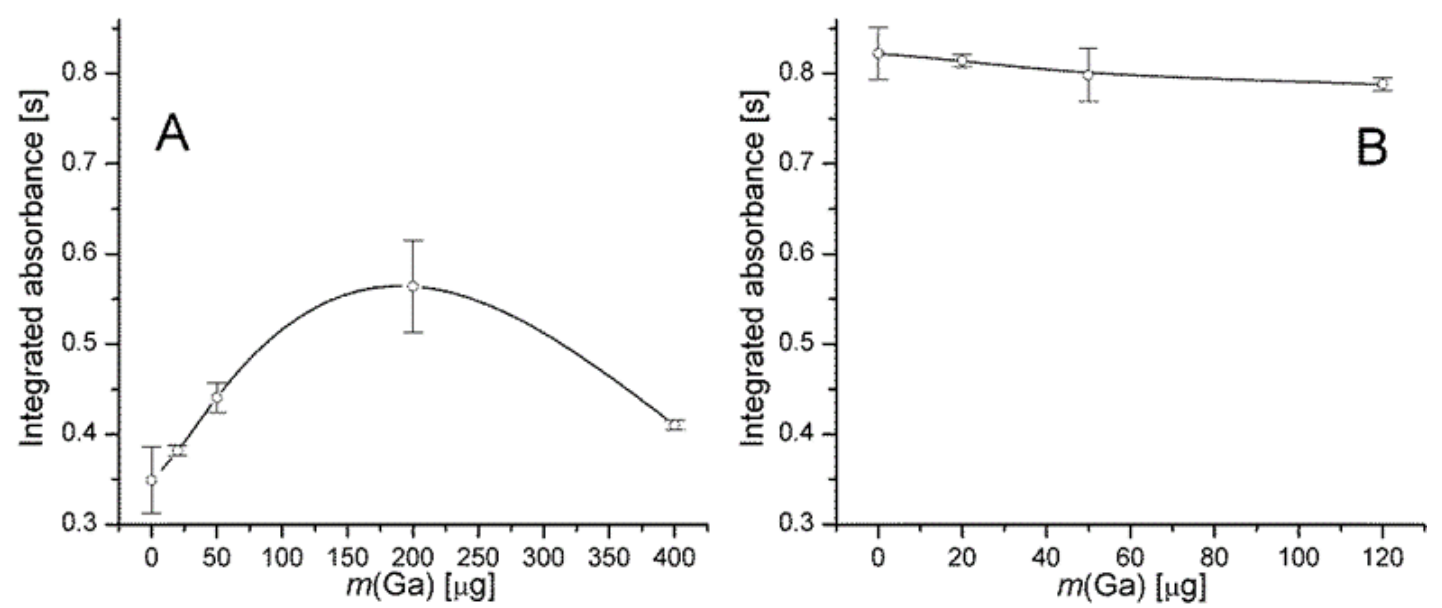

Figure 5. Dependence of GaF molecule absorbance at $211.248 \mathrm{~nm}$ on Ga mass added to the sample solution after furnace pretreatment with $60 \mu \mathrm{g}(\mathrm{A})$ and $800 \mu \mathrm{g}(\mathbf{B})$ of $\mathrm{Ga} ; \mathrm{T}_{\text {pyrol. }}=600{ }^{\circ} \mathrm{C} ; \mathrm{T}_{\text {vapor. }}=1540{ }^{\circ} \mathrm{C} ; m(\mathrm{Pd})=7.5 \mu \mathrm{g} ; \mathrm{m}(\mathrm{Zr})=0.15 \mu \mathrm{g}$; $m(\mathrm{Ru})=1.0 \mu \mathrm{g} ; m\left(\mathrm{CH}_{3} \mathrm{COONa}\right)=5.0 \mu \mathrm{g}$.

Figure 6 shows an example of the time-resolved molecular absorbance spectrum in the wavelength range of $211.1215 \mathrm{~nm}-211.3732 \mathrm{~nm}$ obtained during the analysis of $\mathrm{F}$ in the form of GaF under different conditions. A sharp absorption band from gallium monofluoride with a spectral width of around $8 \mathrm{pm}$ is situated in the middle of the analyzed spectral range. A signal that appears afterwards and at lower wavelength comes from $\mathrm{Ga}$ atoms [38] due to their presence in the entire system [33]. Some other signals from $\mathrm{Ga}$ atoms may be expected in the target spectral range, but they are significantly smaller, than the one that can be seen on Figure 6, thus can be neglected. The application of the proposed modifiers set suppresses this signal, so it does not interfere with the band of GaF. As it can be seen at Figure 6, no other signals of interferences can be found in the studied spectral range. In particular, the signal from phosphorus monoxide could originating from the biological matrix, but it is not observed (Figure 6D). The signal at $211.248 \mathrm{~nm}$ is proportional to the amounts of gallium. It is essentially important that plots on Figure 6C,D for water and bovine liver digest, respectively, are very similar, which means that the possible matrix effects are limited. 

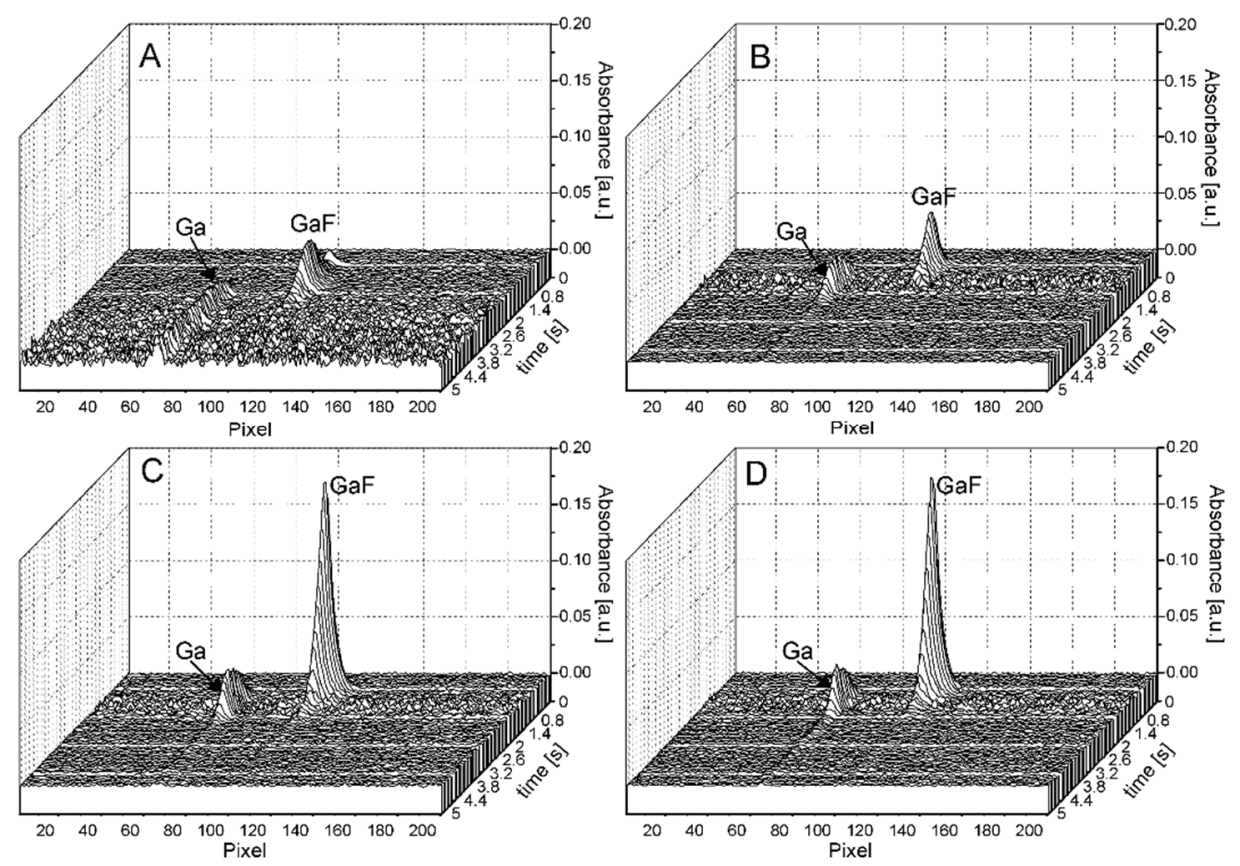

Figure 6. Time- and wavelength-resolved absorbance spectrum during the analysis of F (NaF SRM) in a form of $\mathrm{GaF}$ (pixels correspond to the wavelength range between $211.1215 \mathrm{~nm}$ and $211.3732 \mathrm{~nm}$ ) without modifiers (A) $1 \mathrm{ng}$ F in water, and with modifiers: (B) $0.2 \mathrm{ng} F$ in water; (C) $1 \mathrm{ng}$ F in water; (D) $1 \mathrm{ng} F$ added to bovine liver matrix. Modifiers: $m(\mathrm{Pd})=7.5 \mu \mathrm{g} ; m(\mathrm{Zr})=0.15 \mu \mathrm{g} ; m(\mathrm{Ru})=1.0 \mu \mathrm{g}$; $m\left(\mathrm{Ga}_{\text {pretr. }}\right)=500 \mu \mathrm{g} ; m\left(\mathrm{Ga}_{\text {sol. }}\right)=20 \mu \mathrm{g} ; m\left(\mathrm{CH}_{3} \mathrm{COONa}\right)=5.0 \mu \mathrm{g}$.

\subsection{Method Validation}

Validation covers the entire analytical procedure, including biological sample preparation (acid digestion) as well as instrumental parameters (time/temperature program, reagents amount, wavelength) that provided the highest signal response from $\mathrm{GaF}$. The selected reagent concentrations and volumes are listed in Table 2, together with their mode of application.

Table 2. Concentrations and volumes of the modifier solutions and the Ga reagent used for thermal pretreatment and injection together with the sample.

\begin{tabular}{cccc}
\hline $\begin{array}{c}\text { Mode } \\
\text { of Application }\end{array}$ & Components & Concentration & Volume $[\mu \mathrm{L}]$ \\
\hline Thermal deposition & $\mathrm{Pd}+\mathrm{Zr}$ & $0.15 \% \mathrm{~m} / \mathrm{v} \mathrm{Pd}$ & 5 \\
Thermal deposition & $\mathrm{Ga} \mathrm{in} \mathrm{HNO}_{3}$ & $20 \mathrm{mg} / \mathrm{L} \mathrm{Zr}$ & 25 \\
Added with the sample & $\mathrm{Ru} \mathrm{in} \mathrm{HCl}$ & $0.2 \mathrm{~g} / \mathrm{L} \mathrm{Ru}$ & 5 \\
Added with the sample & $\mathrm{Ga} \mathrm{in} \mathrm{HNO}_{3}$ & $2 \mathrm{~g} / \mathrm{L}$ & 10 \\
Added with the sample & $\mathrm{CH}_{3} \mathrm{COONa}_{2}$ & $1 \mathrm{~g} / \mathrm{L}$ & 5 \\
Added in step 7 & sample or standard & variable & 20 \\
\hline
\end{tabular}

Sodium acetate was used as to create a buffer and prevent losses of fluorine in the form of HF during the drying and pyrolysis stages. The improved procedure, which includes the process of acid digestion, allows for the determination of fluorine in samples at low $\mathrm{pH}$ values of their solutions (up to $C\left(\mathrm{H}^{+}\right)=7 \mathrm{~mol} / \mathrm{L}$ ), which is unique and advantageous in the context of the analysis of biological samples. Notably, fluorine determination independent of its solution $\mathrm{pH}$ is inaccessible by the widely used ISE method.

The equation for quantification of $\mathrm{F}$ taken from the calibration curve was $\mathrm{y}=0.102 \mathrm{x}+0.1302$, where $x$ - the concentration of fluorine; $y$-integrated absorbance. The coefficient of determination $\left(R^{2}\right)$ and the characteristic mass $\left(m_{0}\right)$ of the reported method were 0.9992 and $8.7 \mathrm{pg}$ of 
F, respectively. The calculated LOD of the method was constituted on the basis of three times the standard deviation of 10 repetitive blank measurements (using all the reagents listed in Table 2 and replacing the sample with deionized water) divided by the slope of the calibration curve. Thus, the LOD for $20 \mu \mathrm{L}$ of sample volume was $0.43 \mu \mathrm{g} / \mathrm{L}$ of $\mathrm{F}$ and $8.5 \mathrm{pg}$ of absolute $\mathrm{F}$, respectively. This is comparable with other reports that applied HR-CS GF MAS with GaF formation (4 pg-33 pg of absolute F [2,14,27,28,30,33]). It is worth mentioning that such a low LOD cannot be reached using other molecule-forming agents $(\mathrm{Ca}, \mathrm{Sr}$ or $\mathrm{Al})[15,17,19]$. The linear range of calibration was found for $\mathrm{F}$ concentrations to be $2.0 \mu \mathrm{g} / \mathrm{L}-2000 \mu \mathrm{g} / \mathrm{L}$ (40 pg-40 ng of F).

In order to check the robustness of the proposed procedure to potential matrix effects, first a digest of biological CRM (NIST 1577c or MODAS-5) was added directly into the furnace. The concentration of $\mathrm{F}$ was below the limit of detection, so its content in CRMs could be neglected. Then the same set of samples was spiked with a known amount of F standard before acid digestion and they were analyzed according to the proposed procedure. In addition, the samples with high fluorine content were measured in different dilutions and selected results were compared with the fluorine reference values for available water CRMs. An acceptable recovery factor (93-106\%) confirmed the negligible influence of matrix components on the determination of fluorine in biological samples (Table 3). This proves that the improved procedure allows for the determination of fluorine in samples at low $\mathrm{pH}$ values of their solutions after calibration against aqueous standard solutions.

Table 3. Recovery factors for the determination of fluorine in certified reference material of waters and spiked experiment in selected biological certified reference material.

\begin{tabular}{ccccc}
\hline CRM & Origin & $\begin{array}{c}\text { Certified/Added F } \\
\text { Content }[\mu \mathrm{g} / \mathrm{L}]\end{array}$ & $\begin{array}{c}\text { Found F } \\
\text { Content }[\boldsymbol{\mu g} / \mathrm{L}]\end{array}$ & $\begin{array}{c}\text { Recovery } \\
\text { Factor [\%] }\end{array}$ \\
\hline CRANBERRY-05 & lake water & $70 \pm 26$ & $72 \pm 2$ & 103 \\
ONTARIO-12 & lake water & $114 \pm 24$ & $106 \pm 1$ & 93 \\
NIST 1577c & bovine liver & $25^{1}$ & $26.4 \pm 0.3$ & 106 \\
NIST 1577c & bovine liver & $50^{1}$ & $50.0 \pm 1.1$ & 100 \\
MODAS-5 & cod tissue & $25^{1}$ & $25.7 \pm 0.7$ & 103 \\
MODAS-5 & cod tissue & $50^{1}$ & $49.7 \pm 1.0$ & 99 \\
\hline
\end{tabular}

1 according to the spike of the fluoride standard solution.

\section{Conclusions}

An improved analytical procedure has been developed and validated for the determination of trace amount of fluorine in biological samples using the molecular absorption of the GaF molecule. Modifiers and molecule-forming agents were applied in combined mode, both via thermal deposition in graphite furnace and addition to the sample. Thus, the calibration against aqueous standard solutions was possible. By using the complex matrix mixture, it was possible to enhance the pyrolysis temperature, which provides more efficient removal of matrix components. The commonly used ruthenium(III) nitrosyl nitrate was substituted by $\mathrm{RuCl}_{3}$ in $20 \% \mathrm{HCl}$. The sensitivity and the limit of detection obtained are comparable with other reports that applied HR-CS GF MAS, including the one developed in our laboratory. The validated analytical protocol allows to determine low amount of fluorine directly after acid digestion of biological samples, which was impossible using other methods.

Author Contributions: Conceptualization, E.B.; methodology, A.G., A.T., A.R. and E.B., software, A.G. and A.T.; validation A.G., A.T. and A.R.; formal analysis, A.G. and A.T.; investigation, A.G., A.T., A.R. and E.B.; resources, A.T. and E.B.; data curation, A.G. and A.T.; writing-original draft preparation, A.G., A.T., A.R. and E.B.; writing-review and editing, A.G., A.T., A.R. and E.B.; visualization, A.G. and A.T. and supervision, E.B. All authors have read and agreed to the published version of the manuscript.

Funding: This research received no external funding. 
Institutional Review Board Statement: Not applicable.

Informed Consent Statement: Not applicable.

Data Availability Statement: The data presented in this study are available on request from the corresponding author. The data are not publicly available due to department requirements.

Acknowledgments: The study was carried out at the Biological and Chemical Research Centre, University of Warsaw established within the project co-financed by European Union from the European Regional Development Fund under the Operational Programme Innovative Economy 2007-2013. The study was financed by "Excellence Initiative-Research University (2020-2026)" under the programme of the Ministry of Science and Higher Education of Poland.

Conflicts of Interest: The authors declare no conflict of interest.

\section{References}

1. Brauns, D.H. Quantitative determination of fluorine in organic compounds. J. Res. Natl. Bur. Stand. (1934) 1941, $27,105$. [CrossRef]

2. Gleisner, H.; Welz, B.; Einax, J.W. Optimization of fluorine determination via the molecular absorption of gallium mono-fluoride in a graphite furnace using a high-resolution continuum source spectrometer. Spectrochim. Acta Part B At. Spectrosc. 2010, 65, 864-869. [CrossRef]

3. Borjigin, S.; Ashimura, Y.; Yoshioka, T.; Mizoguchi, T. Determination of Fluoride Using Ion-selective Electrodes in the Presence of Aluminum. Anal. Sci. 2009, 25, 1437-1443. [CrossRef]

4. Hang, Y.-P.; Liu, J.-M. Determination of fluoride by an ion chromatography system using the preconcentration on nanometer-size zirconia. J. Anal. Chem. 2007, 62, 583-587. [CrossRef]

5. Barghouthi, Z.; Amereih, S. Spectrophotometric Determination of Fluoride in Groundwater Using Resorcin Blue Complexes. Am. J. Anal. Chem. 2012, 03, 651-655. [CrossRef]

6. Stacewicz, T.; Bulska, E.; Ruszczyńska, A. Cavity Ring-Down Spectroscopy coupled with helium microwave-induced plasma for fluorine detection. Spectrochim. Acta Part B At. Spectrosc. 2010, 65, 306-310. [CrossRef]

7. Bulska, E.; Jȩdral, W. Application of palladium- and rhodium-plating of the graphite furnace in electrothermal atomic absorption spectrometry. J. Anal. At. Spectrom. 1995, 10, 49-53. [CrossRef]

8. Bulska, E.; Kandler, W.; Hulanicki, A. Noble metals as permanent modifiers for the determination of mercury by electrothermal atomic absorption spectrometry. Spectrochim. Acta Part B At. Spectrosc. 1996, 51, 1263-1270. [CrossRef]

9. Bulska, E. Modifiers in Graphite Furnace Atomic Absorption Spectrometry-Mechanisms and Applications. Encycl. Anal. Chem. 2009, 1-11. [CrossRef]

10. Wojciechowski, M.; Piaścik, M.; Bulska, E. Noble metal modifiers for antimony determination by graphite furnace atomic absorption spectrometry in biological samples. J. Anal. At. Spectrom. 2001, 16, 99-101. [CrossRef]

11. Ortner, H.M.; Bulska, E.; Rohr, U.; Schlemmer, G.; Weinbruch, S.; Welz, B. Modifiers and coatings in graphite furnace atomic absorption spectrometry-Mechanisms of action (A tutorial review). Spectrochim. Acta Part B At. Spectrosc. 2002, 57, 1835-1853. [CrossRef]

12. Welz, B.; Morés, S.; Carasek, E.; Vale, M.G.R.; Okruss, M.; Becker-Ross, H. High-resolution continuum source atomic and molecular absorption spectrometry-A review. Appl. Spectrosc. Rev. 2010, 45, 327-354. [CrossRef]

13. Resano, M.; Flórez, M.R.; García-Ruiz, E. Progress in the determination of metalloids and non-metals by means of high-resolution continuum source atomic or molecular absorption spectrometry. A critical review. Anal. Bioanal. Chem. 2014, 406, 2239-2259. [CrossRef]

14. Heitmann, U.; Becker-Ross, H.; Florek, S.; Huang, M.D.; Okruss, M. Determination of non-metals via molecular absorption using high-resolution continuum source absorption spectrometry and graphite furnace atomization. J. Anal. At. Spectrom. 2006, 21, 1314-1320. [CrossRef]

15. Morés, S.; Monteiro, G.C.; Santos, F.D.S.; Carasek, E.; Welz, B. Determination of fluorine in tea using high-resolution molecular absorption spectrometry with electrothermal vaporization of the calcium mono-fluoride CaF. Talanta 2011, 85, $2681-2685$. [CrossRef]

16. Ozbek, N.; Akman, S. Determination of fluorine in milk samples via calcium-monofluoride by electrothermal molecular absorption spectrometry. Food Chem. 2013, 138, 650-654. [CrossRef] [PubMed]

17. Ozbek, N.; Akman, S. Method development for the determination of fluorine in water samples via the molecular absorption of strontium monofluoride formed in an electrothermal atomizer. Spectrochim. Acta Part B At. Spectrosc. 2012, 69, 32-37. [CrossRef]

18. Ozbek, N.; Akman, S. Molecule Formation Mechanisms of Strontium Mono Fluoride in High-Resolution Continuum Source Electrothermal Atomic Absorption Spectrometry. Anal. Sci. 2013, 29, 741-746. [CrossRef]

19. Aramendía, M.; Flórez, M.R.; Piette, M.; Vanhaecke, F.; Resano, M. Al determination in whole blood samples as AlF via highresolution continuum source graphite furnace molecular absorption spectrometry: Potential application to forensic diagnosis of drowning. J. Anal. At. Spectrom. 2011, 26, 1964-1973. [CrossRef] 
20. Bücker, S.; Acker, J. Spectrometric analysis of process etching solutions of the photovoltaic industry-Determination of HNO3, HF, and H2SiF 6 using high-resolution continuum source absorption spectrometry of diatomic molecules and atoms. Talanta 2012, 94, 335-341. [CrossRef]

21. Boschetti, W.; Dessuy, M.B.; Pizzato, A.H.; Vale, M.G.R. New analytical method for total fluorine determination in soil samples using high-resolution continuum source graphite furnace molecular absorption spectrometry. Microchem. J. 2017, 130, $276-280$. [CrossRef]

22. Machado, P.M.; Morés, S.; Pereira, É.R.; Welz, B.; Carasek, E.; De Andrade, J.B. Fluorine determination in coal using highresolution graphite furnace molecular absorption spectrometry and direct solid sample analysis. Spectrochim. Acta Part B At. Spectrosc. 2015, 105, 18-24. [CrossRef]

23. Ozbek, N.; Akman, S. Solid sampling determination of total fluorine in baby food samples by high-resolution continuum source graphite furnace molecular absorption spectrometry. Food Chem. 2016, 211, 180-184. [CrossRef]

24. Ozbek, N.; Akman, S. Optimization and Application of a Slurry Sampling Method for the Determination of Total Fluorine in Flour Using a High-Resolution Continuum Source Graphite Furnace Molecular Absorption Spectrometer. Food Anal. Methods 2016, 9, 2925-2932. [CrossRef]

25. Ozbek, N.; Akman, S. Application of Solid Sampling for the Determination of Total Fluorine in Fish and Seafood by HighResolution Continuum Source Graphite Furnace Molecular Absorption Spectrometry. Anal. Lett. 2018, 51, 2776-2789. [CrossRef]

26. Borges, A.R.; Duarte, Á.T.; da Potes, M.L.; Silva, M.M.; Vale, M.G.R.; Welz, B. Fluorine in eye shadow: Development of method using high-resolution continuum source graphite furnace molecular absorption spectrometry via calcium mono-fluoride with direct solid sample introduction. Microchem. J. 2016, 124, 410-415. [CrossRef]

27. Gleisner, H.; Einax, J.W.; Morés, S.; Welz, B.; Carasek, E. A fast and accurate method for the determination of total and soluble fluorine in toothpaste using high-resolution graphite furnace molecular absorption spectrometry and its comparison with established techniques. J. Pharm. Biomed. Anal. 2011, 54, 1040-1046. [CrossRef] [PubMed]

28. Qin, Z.; McNee, D.; Gleisner, H.; Raab, A.; Kyeremeh, K.; Jaspars, M.; Krupp, E.; Deng, H.; Feldmann, J. Fluorine speciation analysis using reverse phase liquid chromatography coupled off-line to continuum source molecular absorption spectrometry (CS-MAS): Identification and quantification of novel fluorinated organic compounds in environmental and biologica. Anal. Chem. 2012, 84, 6213-6219. [CrossRef]

29. Qin, Z.; Raab, A.; Krupp, E.; Deng, H.; Feldmann, J. Mining complex bacteria media for all fluorinated compounds made possible by using HPLC coupled parallel to fluorine-specific and molecular specific detection. J. Anal. At. Spectrom. 2013, $28,877$. [CrossRef]

30. Würtenberger, I.; Gust, R. A highly sensitive method for in vitro testing of fluorinated drug candidates using high-resolution continuum source molecular absorption spectrometry (HR-CS MAS). Anal. Bioanal. Chem. 2014, 406, 3431-3442. [CrossRef]

31. Metzger, M.; Ley, P.; Sturm, M.; Meermann, B. Screening method for extractable organically bound fluorine (EOF) in river water samples by means of high-resolution-continuum source graphite furnace molecular absorption spectrometry (HR-CS GF MAS). Anal. Bioanal. Chem. 2019, 411,4647-4660. [CrossRef]

32. Gehrenkemper, L.; Simon, F.; Roesch, P.; Fischer, E.; von der Au, M.; Pfeifer, J.; Cossmer, A.; Wittwer, P.; Vogel, C.; Simon, F.G.; et al. Determination of organically bound fluorine sum parameters in river water samples—comparison of combustion ion chromatography (CIC) and high resolution-continuum source-graphite furnace molecular absorption spectrometry (HR-CSGFMAS). Anal. Bioanal. Chem. 2021, 413, 103-115. [CrossRef] [PubMed]

33. Krüger, M.; Huang, M.-D.; Becker-Roß, H.; Florek, S.; Ott, I.; Gust, R. Quantification of the fluorine containing drug 5-fluorouracil in cancer cells by GaF molecular absorption via high-resolution continuum source molecular absorption spectrometry. Spectrochim. Acta Part B At. Spectrosc. 2012, 69, 50-55. [CrossRef]

34. Gawor, A.; Konopka, A.; Ruszczyńska, A.; Paczek, L.; Gajewski, Z.; Bulska, E. Molecular absorption and mass spectrometry for complementary analytical study of fluorinated drugs in animal organisms. J. Anal. At. Spectrom. 2020, 35, 1840-1847. [CrossRef]

35. Kowalewska, Z.; Brzezińska, K.; Zieliński, J.; Pilarczyk, J. Method development for determination of organic fluorine in gasoline and its components using high-resolution continuum source flame molecular absorption spectrometry with gallium fluoride as a target molecule. Talanta 2021, 227, 122205. [CrossRef]

36. Ley, P.; Sturm, M.; Ternes, T.A.; Meermann, B. High-resolution continuum source graphite furnace molecular absorption spectrometry compared with ion chromatography for quantitative determination of dissolved fluoride in river water samples. Anal. Bioanal. Chem. 2017, 409, 6949-6958. [CrossRef] [PubMed]

37. Huang, M.D.; Becker-Ross, H.; Florek, S.; Heitmann, U.; Okruss, M. The influence of calcium and magnesium on the phosphorus monoxide molecular absorption signal in the determination of phosphorus using a continuum source absorption spectrometer and an air-acetylene flame. J. Anal. At. Spectrom. 2006, 21, 346-349. [CrossRef]

38. Shirai, T.; Reader, J.; Kramida, A.E.; Sugar, J. Spectral Data for Gallium: Ga I through Ga XXXI. J. Phys. Chem. Ref. Data 2007, 36, 509-615. [CrossRef] 